\title{
Etnomatematika pada Buku Saku Digital Berbasis Android Materi Segitiga dan Segiempat MTs
}

\author{
Muhammad Sholeh ${ }^{1}$, Nanang Supriadi ${ }^{2 *}$, \& Suherman $^{3}$ \\ 1, 2, 3Universitas Islam Negeri Raden Intan Lampung, Bandar Lampung, Indonesia
}

\begin{tabular}{l} 
INFO ARTICLES \\
\hline Article History: \\
Received: 03-03-2021 \\
Revised: 03-05-2021 \\
Approved: 22-06-2021 \\
Publish Online: $30-06-2021$ \\
\hline
\end{tabular}

Key Words:

A Digital Pocket Book; Android; Ethnomathematics;

under a Creative Commons AttributionShareAlike 4.0 International License.

\begin{abstract}
Abtract: This research aims to produce a digital pocket book that is declared valid, suitable, interesting, and effective for use as a medium for learning mathematics. This research is a research and development $(R \& D)$ with a $4 D$ development model from Thiagarajan which consists of 4 steps, namely: define, design, develop, and disseminate. The subjects of this research were students of class VII MTs in Lampung district. The research instruments used interviews, material and media expert validator questionnaires, student attractiveness response questionnaires, and tests. The results of validation material expert and media expert obtained scores of 3.69 and 3.75 with the criteria "feasible", the results of the small and large group trials obtained a score of 3.7 and 3.79 with the criteria "very interesting", while the results of the effectiveness test obtained an N-gain score of 0.72 in the "high" category. The conclusion is that an android based digital pocket book characterized by ethnomathematics is declared valid, feasible, interesting, and effective as a medium for learning mathematics.
\end{abstract}

\begin{abstract}
Abstrak: Penelitian ini bertujuan untuk menghasilkan buku saku digital yang valid, layak, menarik dan efektif sebagai media pembelajaran matematika. Penelitian ini merupakan penelitian pengembangan atau Research and Development $(R \& D)$ dengan model pengembngan $4 \mathrm{D}$ dari Thiagarajan yang terdiri atas 4 langkah yaitu: define (pendefinisian), design (perancangan), develop (pengembangan), dan disseminate (penyebaran). Subjek dari penelitian ini adalah peserta didik kelas VII MTs di Kabupaten Lampung Barat. Instrumen penelitian yang digunakan yaitu wawancara, angket validator ahli materi dan media, angket respon kemenarikan peserta didik, dan tes. Hasil validasi ahli materi dan ahli media memperoleh skor 3,69 dan 3,75 dengan kriteria "layak", hasil uji coba kelompok kecil dan kelompok besar memperoleh skor 3,7 dan 3,79 dengan kriteria "sangat menarik", sementara hasil uji efektifitas memperoleh skor $N$-gain sebesar 0,72 dengan ketegori "tinggi". Simpulannya adalah buku saku digital berbasis android bercirikan etnomatematika dinyatakan valid, layak, menarik, dan efektif sebagai media pembelajaran matematika.
\end{abstract}

Correspondence Address: Jl. Letkol H. Endro Suratmin, Kecamatan Sukarame, Kota Bandar Lampung 35131, e-mail: nanangsupriadi@radenintan.ac.id

How to Cite (APA $6^{\text {th }}$ Style): Sholeh, M., Supriadi, N., \& Suherman, S. (2021). Etnomatematika pada Buku Saku Digital Berbasis Android Materi Segitiga dan Segiempat MTs. JKPM (Jurnal Kajian Pendidikan Matematika), 6 (2): 191-204.

Copyright: 2021 Muhammad Sholeh, Nanang Supriadi, Suherman Suherman

Competing Interests Disclosures: The authors declare that they have no significant competing financial, professional or personal interests that might have influenced the performance or presentation of the work described in this manuscript. 


\section{PENDAHULUAN}

Pendidikan merupakan salah satu bagian terpenting dalam kehidupan manusia, serta merupakan aspek utama terbentuknya sumber daya manusia yang berkualitas. Sebagaimana tercantum dalam Pembukaan Undang-Undang Dasar 1945 bahwa tujuan dari pendidikan adalah untuk mencerdaskan kehidupan bangsa (Istikomah \& Purwoko, 2020).

Saat ini perkembangan ilmu pengetahuan telah memasuki era digital, dimana kegiatan belajar mengajar tidak terlepas dari penggunaan teknologi digital (Septiyani \& Apriyanto, 2019). Perkembangan pendidikan tidak luput dari pengaruh perkembangan teknologi digital yang terjadi. Perangkat digital yang marak di kalangan peserta didik adalah smartphone. Hal ini dibuktikan dengan hasil prapenelitian yang peneliti lakukan di MTsN 1 Lampung Barat dan MTs Nurul Ulum Purajaya. Berdasarkan hasil prapenelitian tersebut diperoleh informasi bahwa $98 \%$ peserta didik telah memiliki smartphone. Adapun jenis smartphone yang digunakan peserta didik adalah jenis android. Android merupakan suatu opration system berbasis mobile untuk perangkat digital seperti smartphone dan komputer tablet (Salbino, 2014)

Perkembangan teknologi digital yang terjadi belum dimanfaatkan secara maksimal dalam kegiatan belajar mengajar. Berdasarkan prapenelitian yang dilakukan di MTsN 1 Lampung Barat dan MTs Nurul Ulum Purajaya, diperoleh informasi bahwa $48 \%$ penggunaan smartphone adalah untuk bermain media sosial, $30 \%$ untuk bermain game, $12 \%$ untuk berkomunikasi, dan $10 \%$ untuk kegiatan pembelajaran. Perkembangan teknologi digital semestinya dapat dimanfaatkan sebagai penunjang proses belajar mengajar (Sulistri et al., 2020). Smarphone berbasis android dengan segala kecanggihan fiturnya seharusnya dapat digunakan untuk membantu peserta didik dalam proses pembelajaran, seperti pemanfaatan mobile apps sebagai media pembelajaran yang merupakan salah satu teknologi dengan prospektif tinggi di masa depan. Hal ini dikarenakan mobile apps memiliki fleksibilitas dan portabilitas yang tinggi khususnya dalam pembelajaran matematika, dimana terdapat beberapa materi yang membutuhkan pemahaman yang kuat. Oleh karena itu, mobile apps dapat dijadikan sebagai media pembelajaran yang representatif dan bisa diulang-ulang kapanpun dan dimanapun siswa membutuhkannya (Basya et. al., 2019)

Salah satu mobile apps yang dapat membantu proses pembelajaran peserta didik adalah buku saku digital. Menurut kamus Besar Bahasa Indonesia, buku saku adalah buku berukuran kecil yang dapat disimpan dalam saku dan mudah dibawa kemana-mana (Asyhari \& Silvia, 2016). Moh. Syahroni mengatakan bahwa buku saku digital ialah buku elektronik yang berisikan informasi berupa teks atau gambar yang dapat ditampilkan di layar digital, dan mudah dibawa kemanapun (Syahroni et al., 2016). Buku ajar seperti buku saku yang dikemas dalam bentuk digital semestinya memiliki nilai lebih dibandingkan dengan buku cetak biasa yang banyak beredar karena menggunakan alat bantu berupa komputer (PC), tablet, maupun smartphone yang dapat menampilkan fitur-fitur berupa gambar, suara, animasi, maupun video (Supriadi, 2015).

Buku saku digital merupakan salah satu mobile apps yang dinilai dapat mendukung proses pembelajaran peserta didik. Karena buku saku digital yang bersifat fleksibel dapat dibawa kemanapun dan digunakan kapanpun. Hal ini didukung oleh hasil wawancara peneliti kepada pendidik di MTsN 1 Lampung Barat dan MTs Nurul Ulum Purajaya. Berdasarkan wawancara tersebut diperoleh informasi bahwa peserta didik masih menggunakan media pembelajaran cetak seperti buku paket, modul dan LKPD, dimana media tersebut memiliki ukuran yang relatif besar dan sedikit menyulitkan jika harus dibawa ke mana-mana. Oleh karenanya diperlukan adanya media pembelajaran yang ringan, tidak memakan tempat, dapat dibawa kemana-mana dan dapat digunakan kapan saja.

Selain itu, hasil wawancara juga diperoleh bahwa peserta didik memerlukan media pembelajaran yang menarik terkhusus pada pelajaran matematika yang notabene dianggap sulit dan membosankan. Oleh karena itu, peneliti tertarik mengembangkan media pembelajaran yang menarik yaitu media pembelajaran yang bercirikan etnomatematika. Etnomatematika merupakan 
matematika yang tumbuh dan berkembang dalam kebudayaan tertentu seperti kumpulan norma atau aturan yang berlaku di masyarakat, kepercayaan, dan nilai yang diakui pada kelompok masyarakat yang berada pada suku atau kelompok bangsa yang sama (Suherman, 2018). Etnomatematika dipilih karena sangat berkaitan dan berdampingan erat dengan kehidupan seharihari peserta didik. Hal ini tetunya akan lebih menarik bagi peserta didik dan lebih mudah untuk memahami materi yang disajikan karena berkaitan langsung dengan kehidupan sehari-hari mereka (Arif et. al., 2019). Selain itu, etnomatematika belum pernah diterapkan dalam media yang digunakan di sekolah tempat peneliti melakukan penelitian. Berdasarkan permasalahan yang telah diuraikan di atas, yaitu perlu adanya media pembelajaran yang dapat mengikuti perkembangan teknologi, menarik, mudah dibawa kemanapun dan digunakan kapanpun, maka peneliti tertarik mengembangkan buku saku digital berbasis android bercirikan etnomatematika sebagai salah satu media pembelajaran yang dapat mendukung proses pembelajaran peserta didik.

Penelitian-penelitian mengenai buku saku digital pernah dilakukan oleh peneliti terdahulu dinataranya adalah pengembangan buku saku digital berbasis android sebagai pendukung bahan ajar pada materi PPh pasal 21 (Yaqin \& Rochmawati, 2017), pengembangan media pembelajaran berbasis android dalam bentuk buku saku digital untuk mata pelajaran akuntansi kompetensi dasar membuat ikhtisar siklus akuntansi perusahaan jasa di kelas XI MAN 1 Yogyakarta tahun ajaran 2014/2015 (Oktiana, 2015), pengembangan buku saku digital berbasis android pada materi matriks berdasarkan kurikulum 2013 di kelas XI IPS 3 SMA Negeri 2 (Muhdiyanto, 2018), pengembangan buku saku elektronik berbasis android tentang signal-signal wasit futsal untuk wasit futsal di kabupaten Pasuruan (Syahroni et. al., 2016), pengembangan buku saku pintar gizi untuk siswa smp: alternatif media pembelajaran untuk meningkatkan pengetahuan gizi olahraga (Festiawan \& Arovah, 2020), dan pengembangan buku saku materi mamalia di taman margasatwa ragunan untuk meningkatkan penguasaan konsep siswa (Awaludin \& Rostikawati, 2020). Buku saku digital yang peneliti kembangkan merupakan buku saku digital yang bercirikan atau bernuansa etnomatematika sebagai sebuah novelty atau kebaruan, dimana belum pernah dikembangkan pada penelitian-penelitian seblumnya.

Penelitian-penelitian mengenai etnomatematika pernah dilakukan oleh peneliti terdahulu diantaranya adalah pengembangan modul pembelajaran matematika berbasis etnomatematika berbantuan wingeom berdasarkan langkah borg and gall (Rohmaini et. al., 2020), pengembangan media pembelajaran prezi berbasis etnomatematika pada materi bangun datar kelas VII (Anggraeni et. al., 2020), pengembangan lembar kerja peserta didik berbasis etnomatematika pada materi segitiga dan segiempat (Rewatus et. al., 2020), pengembangan lks berbasis etnomatematika (budaya Lubuklinggau) untuk menumbuhkan motivasi belajar matematika siswa (Luthfiana et. al., 2020), pengembangan media game visual novel berbasis etnomatematika untuk meningkatkan pemahaman konsep pada materi aljabar (Jabali et. al., 2020), dan pengembangan bahan ajar matematika berbasis etnomatematika untuk meningkatkan pemahaman matematik siswa kelas III sekolah dasar (Muhammad \& Novitasari, 2020). Pada penelitian-penelitian sebelumnya, etnomatematika belum pernah diterapkan atau dipadukan dalam sebuah buku saku digital. Sebagai sebuah kebaruan atau novelty pada penelitian ini peneliti akan memadukan atau menerapkan konsep etnomatematika dalam buku saku digital yang akan peneliti kembangkan.

Etnomatematika pada buku saku digital ini tercermin pada desain dan tampilan di dalamnya, dimana seluruh disain lay out dari buku saku digital ini bermotif Tapis (kain khas Lampung) dan Celugam (batik khas Lampung Barat). Selain pada lay out etnomatematika juga tercermin pada cover buku saku digital ini, dimana terdapat gambar Nuwo Sesat (rumah adat Lampung) dan Siger (mahkota berwarna emas yang biasa digunakan wanita suku Lampung dalam acara pernikahan dan juga merupakan ikon kebanggaan masyarakat Lampung). Etnomatematika juga tercermin pada materi dan latihan yang digunakan pada buku saku digital ini, seperti Gamolan atau Cetik (alat musik khas Lampung) pada materi persegi panjang, Celugam (batik khas Lampung Barat) pada 
materi persegi, serta Nuwo Sesat atau Nuwo Balak (rumah adat Lampung) pada materi trapesium dan segitiga.

Berdasarkan pemaparan di atas, tujuan dari penelitian ini adalah mengembangkan buku saku digital berbasis android bercirikan etnomatematika, mengetahui kelayakan produk berupa buku saku digital berbasis android bercirikan etnomatematika, dan mengetahui respon peserta didik terhadap buku saku digital berbasis android bercirikan etnomatematika sebagai salah satu media pembelajaran matematika materi segitiga dan segiempat MTs kelas VII.

Etnomatematika pada buku saku digital ini tercermin pada desain dan tampilan di dalamnya, dimana seluruh disain lay out dari buku saku digital ini bermotif Tapis (kain khas Lampung) dan Celugam (batik khas Lampung Barat). Selain pada lay out etnomatematika juga tercermin pada cover buku saku digital ini, dimana terdapat gambar Nuwo Sesat (rumah adat Lampung) dan Siger (mahkota berwarna emas yang biasa digunakan wanita suku Lampung dalam acara pernikahan dan juga merupakan ikon kebanggaan masyarakat Lampung). Etnomatematika juga tercermin pada materi dan latihan yang digunakan pada buku saku digital ini, seperti Gamolan atau Cetik (alat musik khas Lampung) pada materi persegi panjang, Celugam (batik khas Lampung Barat) pada materi persegi, serta Nuwo Sesat atau Nuwo Balak (rumah adat Lampung) pada materi trapesium dan segitiga.

\section{METODE}

Penelitian ini berjenis Research and Development $(R \& D)$ atau yang lebih dikenal sebagai penelitian dan pengembangan. Research and Development $(R \& D)$ adalah penelitian yang dilaksanakan untuk mengembangkan atau menghasilkan suatu produk yang kemudian dilakukan pengujian keefektifan produk tersebut. Pengujian keefektifan produk tersebut dimaksudkan untuk mengetahui apakah produk tersebut layak digunakan dalam masyarakat luas atau tidak (Sugiyono, 2015).

Metode penelitian yang digunakan dalam penelitian ini merupakan metode yang dikembangkan oleh Sivasailam Thiagarajan, Dorothy S. Semmel, dan Melyn I Semmel, yaitu metode pengembangan perangkat model 4D (Four D Model). Tahapan untuk melaksanakan model ini dibagi menjadi 4 bagian seperti pada Gambar 1. (Kristanti \& Julia, 2018).

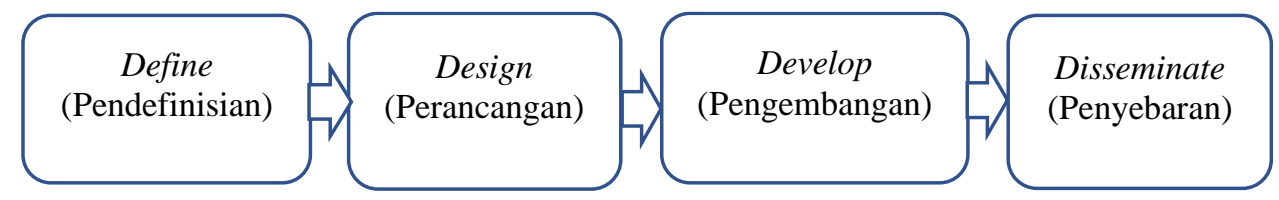

Gambar 1. Tahapan Model 4D

a. Define (Pendefinisian)

Define merupakan tahapan pertama yang dilakukan guna mengumpulkan data awal untuk mengetahui potensi dan kebutuhan peserta didik di lapangan untuk dicarikan solusinya (Ramadhani, 2016). Tahapan ini terdiri dari beberapa langkah sebagai berikut: (1) Front-end Analysis (Analisis Awal); (2) Concept Analysis (Analisis Konsep); (3) Task Analysis (Analisis Tugas); (4) Specifyng Instructional Objective (Penentuan Tujuan Pembelajaran).

b. Design (Perancangan)

Design atau perancangan adalah tahapan yang dilakukan dengan tujuan untuk mendesain atau merancang draft prototipe produk yang akan dikembangkan (Ramadhani, 2016). Tahapan ini memiliki langkah-langkah sebagai berikut: (1) Constructing Criterionreferenced Test (Penyusunan kriteria Tes); (2) Media Selection (Pemilihan Media); (3) Format Selection (Pemilihan Format); (4) Initial Design (Desain Awal).

c. Develop (Pengembangan)

Develop atau pengembangan adalah tahapan yang bertujuan untuk menghasilkan suatu produk tertentu yang kemudian akan divalidasi oleh para ahli (Khoiriyah \& Sari, 2018). 
Tahapan ini merupakan tahapan dimana semua proses pembuatan, validasi, dan pengujian dilakukan (Kristanti \& Julia, 2018). Tahapan ini memiliki beberapa langkah yaitu: (1) Validasi Produk; (2) Revisi Produk; (3) Uji Coba Croduk; (4) Uji Efektivitas Produk.

d. Disseminate (Penyebaran)

Disseminate atau penyebaran merupakan tahapan terakhir dari model pengembangan 4D. Tahapan ini bertujuan untuk memperkenalkan dan mempromosikan produk yang telah dikembangkan kepada pengguna (Ferdianto \& Setiyani, 2018).

Penelitian ini dilaksanakan pada MTs di kabupaten Lampung Barat. Subjek dari penelitian ini yaitu peserta didik kelas VII MTs di kabupaten Lampung Barat. Instrument pengumpulan data dalam penelitian ini yaitu: (1) Wawancara; (2) Lembar Validasi; (3) Angket respon peserta didik; (4) Soal tes. Pengembangan buku saku digital ini menggunakan teknik analisis deskriptif kualitatif. Teknik ini memaparkan hasil dari pengembangan produk yang dikembangkan. Hasil penilaian produk buku saku digital ini akan dicari rata-ratanya untuk mengetahui kriteria kelayakannya (Putra \& Anggraini, 2016).

Analisis data validasi ahli terdiri dari 4 pilihan jawaban dengan tiap-tiap skor yang berbeda. Jawaban tersebut memiliki gradasi nilai 1 sampai 4 dengan kriteria kemenarikan seperti pada Tabel 1.

Tabel 1 . Kriteria Penilaian Validasi Ahli (Modifikasi)

\begin{tabular}{lll}
\hline Skor Kuaitas & Kriteria Kelayakan & Keterangan \\
\hline $3,26<\bar{X} \leq 4,00$ & Layak Digunakan & Tidak Revisi \\
$2,51<\bar{X} \leq 3,26$ & Cukup Layak digunakan & Revisi Sebagian \\
$1,67<\bar{X} \leq 2,51$ & Kurang layak digunakan & Revisi Sebagian \& Pengkajian Ulang Materi \\
$1,00<\bar{X} \leq 1,76$ & Tidak layak digunakan & Revisi Total \\
\hline (Latifah, 2016) & &
\end{tabular}

Analisis data uji coba produk atau angket respon peserta didik memiliki 4 jawaban dengan masing-masing skor berbeda. Jawaban tersebut memiliki gradasi nilai 1 sampai 4 dengan kriteria kemenarikan seperti pada Tabel 2.

Tabel 2. Kriteria Penilaian Uji Coba Kemenarikan Produk (Modifikasi)

\begin{tabular}{ll}
\hline Skor Kualitas & Kriteria Kemenarikan \\
\hline $3,26<\bar{X} \leq 4,00$ & Sangat Menarik \\
$2,51<\bar{X} \leq 3,26$ & Menarik \\
$1,76<\bar{X} \leq 2,51$ & Kurang Menarik \\
$1,00 \leq \bar{X} \leq 1,76$ & Sangat Kurang Menarik \\
\hline
\end{tabular}

(Putra \& Anggraini, 2016)

Analisis efektivitas produk dapat dilihat dari selisish hasil pretest dan posttest yang dilakukan peserta didik. Selanjutnya dilakukan perhitungan dengan rumus normalitas gain ( $N$ gain) (Adawiyah et. al., 2018). Kriteria penentuan tinggi rendahnya nilai $\mathrm{N}$-gain dapat ditentukan berdasarkan Tabel 3. (Wahyuni et. al., 2020).

Tabel 3. Tabel Kriteria Skor $N$-gain

\begin{tabular}{cc}
\hline Batasan & Kategori \\
\hline$g \geq 0,70$ & Tinggi \\
$0,30 \leq g<0,70$ & Sedang \\
$g<0,30$ & Rendah \\
\hline
\end{tabular}




\section{HASIL}

Berikut ini merupakan penjabaran dari tahapan hasil penelitian dan pengembangan buku saku digital berbasis android bercirikan etnomatematika:

1. Tahapan Define (Pendefinisian)

a. Front-end Analysis (Analisis Awal)

Analisis ini merupakan tahapan awal dalam melaksanakan penelitian dan pengembangan dengan dengan cara melakukan wawancara kepada pendidik dan memberikan angket kuesioner kepada peserta didik. Berdasarkan hasil wawancara kepada pendidik dan angket yang diberikan kepada peserta didik, diperoleh hasil bahwa buku saku digital berbasis android bercirikan etnomatematika perlu dikembangkan. Hal ini dikarenakan perkembangan teknologi berupa smartphone berbasis android di kalagan pelajar. Berdasarkan hasil angket yang diberikan kepada peserta didik hampir seluruh peserta didik telah difasilitasi dan memiliki smartphone terlebih lagi di saat adanya pandemi seperti saat ini yang mengharuskan pembelajaran dilakukan secara daring. Selain itu, berdasarkan wawancara kepada pendidik juga diperoleh hasil bahwa peserta didik memerlukan media pembelajaran yang dapat mengikuti perkembangan zaman, mudah dibawa dan digunakan kapan saja, serta selalu melekat dengan peserta didik. Hal ini dikarenakan peserta didik lebih sering membawa gawai mereka dari pada harus membawa buku ke mana-mana. Oleh karena itu, buku saku digital berbasis android bercirikan etnomatematika perlu dikembangan sebagai salah satu alternatif media pembelajaran bagi peserta didik.

b. Concept Analysis (Analisis Konsep)

Tahapan ini dilakukan dengan cara melakukan wawancara kepada pendidik serta menganalisis dan mempelajari sub-sub dalam materi yang relevan untuk digunakan dalam produk yang akan dikembangkan. Analisis ini bertujuan untuk mengidentifikasi bagianbagian penting yang akan dipelajari dan menyusunnya dalam bentuk yang sistematis dan relevan pada media pembelajaran. Pada tahap analisis konsep ini diperoleh hasil sebagai berikut: (1) Materi yang akan diajarkan yaitu segi empat dan Segitiga; (2) Kompetensi dasarnya yaitu menyelesaikan masalah kontekstual yang berkaitan dengan segiempat dan segitiga.

c. Task Analysis (Analisis Tugas)

Task analysis dilakukan dengan cara menganilisis gambaran dasar terkait tugas-tugas yang dibutuhkan dalam pembelajaran berdasarkan KI dan KD yang berlaku. Analisis ini diawali dengan menganalisa kompetensi dasar selanjutnya menjelaskan indikator pembelajaran. Hasil analisis tugas berdasarkan KI dan KD yang berlaku diperoleh indikator sebagai berikut: (1) Mengenali dan memahami jenis-jenis serta sifat-sifat segi empat dan segitiga; (2) Memahami garis-garis istimewa pada segitiga; (3) Memahami rumus keliling dan luas segi empat dan segitiga; (4) Menyelesaiakan permasalahan yang berkaitan dengan segi empat dan segitiga dalam kehidupan sehari-hari; (5) Menaksir luas bangun datar tak beraturan.

d. Specifyng Instructional Objective (Penentuan Tujuan Pembelajaran)

Hasil dari proses ini yaitu diperoleh tujuan pembelajaran sebagai berikut: (1) Memahami macam-macam segi empat dan sifat-sifatnya; (2) Memahami jenis-jenis segitiga berdasarkan sisi atau sudutnya; (3) Memahami sifat-sifat segitiga; (4) Memahami garis-garis istimewa pada segitiga; (5) Memahami jumlah sudut, sudut dalam, dan sudut luar pada segitiga; (6) Menghitung keliling dan luas pada segi empat dan segitiga; (7) Menyelesaikan permasalahan yang berkaitan dengan segiempat dan segitiga.

2. Tahap Design (Perancangan)

a. Constructing Criterion-referenced Test (Penyusunan Kriteria Tes) 
Constructing criterion-referenced Test Merupakan penyusunan tes berupa angket yang sebelumnya disusun berdasarkan kisi-kisi instrumen angket, kemudian diberikan kepada validator pada saat melakukan validasi. Validasi yang dilakukan yaitu validasi ahli materi, validasi ahli media, serta uji coba kemenarikan peserta didik. Aspek yang dinilai dalam angket validator dan angket respon peserta didik yaitu kualitas isi, tampilan dan kegrafisan, kebahasaan, serta keterlaksanaan.

b. Media Selection (Pemilihan Media)

Media selection merupakan pemilihan media pembelajaran yang sesuai dengan materi dan karakteristik peserta didik. Media pembelajaran yang dipilih peneliti untuk dikembangkan yaitu berupa buku saku digital berbasis android bercirikan etnomatematika.

c. Format Selection (Pemilihan Format)

Format selection merupakan tahapan yang dilakukan untuk memilih format atau bentuk penyajian yang sesuai dengan media pembelajaran yang akan dikembangkan. Peneliti memilih format aplikasi (apk) android sebagai hasil dari produk yang dikembangkan.

d. Initial Design (Desain Awal)

Initial Design yaitu rancangan awal seluruh produk yang harus dikerjakan sebelum validasi dan uji coba dilaksanakan berdasarkan pada analisis dan tahapan-tahapan yang telah dilakukan. Buku saku digital berbasis android bercirikan etnomatematika ini terdiri dari Cover, Home, Kata Pengantar, KI/KD, Peta Konsep dan Tujuan Pembelajaran, Materi (terdiri dari materi, contoh soal, dan video pembelajaran terkait), Latihan, Kuis, Profil Penulis, dan Daftar Pustaka.

3. Tahap Develop (Pengembangan)

a. Validasi

Validasi dilakukan oleh enam orang ahli yaitu tiga orang ahli materi dan tiga orang ahli media. Tujuan validasi ini adalah untuk mengetahui kelayakan dari produk buku saku digital yang telah dikembangkan.

Validasi yang pertama adalah validasi ahli materi yang dilakukan oleh tiga orang ahli yang terdiri dari dua orang pakar dari UIN Raden Intan Lampung yaitu Rizki Wahyu Yunian Putra, M.Pd dan Dona Dinda Pratiwi, M.Pd serta satu praktisi pendidikan yaitu Tri Setyawahyuningsih, S.Pd. Hasil validasi ahli materi dapat dilihat pada Gambar 2.

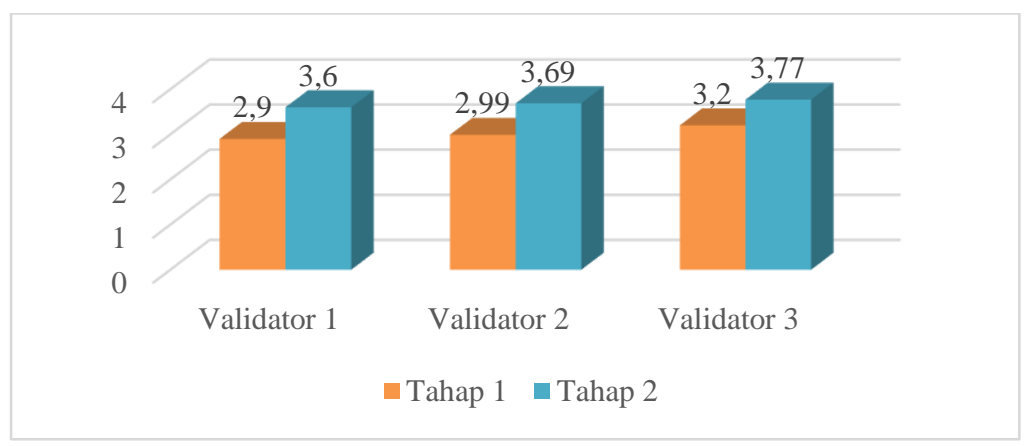

\section{Gambar 2. Hasil Validasi Ahli Materi}

Validasi yang kedua adalah validasi ahli media yang dilakukan oleh tiga orang ahli yang terdiri dari dua orang pakar dari UIN Raden Intan Lampung yaitu Komaridun, M.Pd dan Abi Fadila, M.Pd serta satu praktisi pendidikan yaitu Syarifah Aini, S.Pd. Hasil validasi ahli media dapat dilihat pada Gambar 3. 


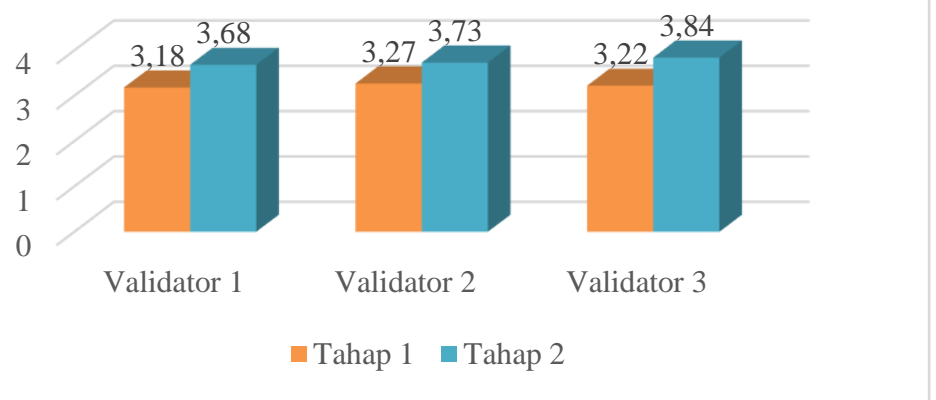

Gambar 3. Hasil Validasi Ahli Media

Gambar 2. menunjukkan hasil validasi ahli materi tahap 1 memperoleh skor ratarata 3,03. Setelah melakukan revisi, terlihat hasil validasi tahap 2 memperoleh rata-rata 3,69 dengan kriteria "Layak". Gambar 3. menunjukkan hasil validasi ahli media tahap 1 memperoleh skor rata-rata 3,22. Setelah melakukan revisi, terlihat hasil validasi tahap 2 memperoleh rata-rata 3,75 dengan kriteria "Layak".

b. Revisi

Setelah melakukan validasi tahap 1, kemudian peneliti mendapat saran dan masukan dari validator untuk merevisi produk yang peneliti kembangkan. Berikut ini merupakan saran dan masukan dari validator: (1) Lengkapi tanda siku-siku, sejajar, dan sama panjang pada setiap bangun; (2) Tambah soal UN (HOTS) setelah latihan; (3) Kuis dibuat lebih dari satu; (4) Jawaban kuis ditampilkan di akhir: (5) Revisi ukuran huruf yang tidak sesuai dan kesalahan pengetikan (typo); (6) Latihan dan kuis dibuat beragam (pilihan ganda, essay singkat, essay panjang, benar salah, dan lain sebagainya). Tampilan beberapa bagian buku saku digital berbasis android bercirikan etnomatematika yang telah direvisi dapat dilihat pada Gambar 4 sampai Gambar 9.

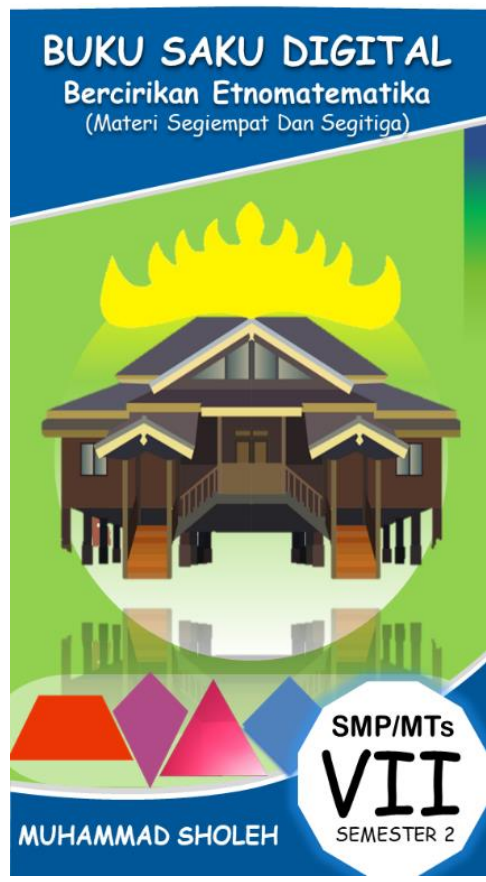

Gambar 4. Cover

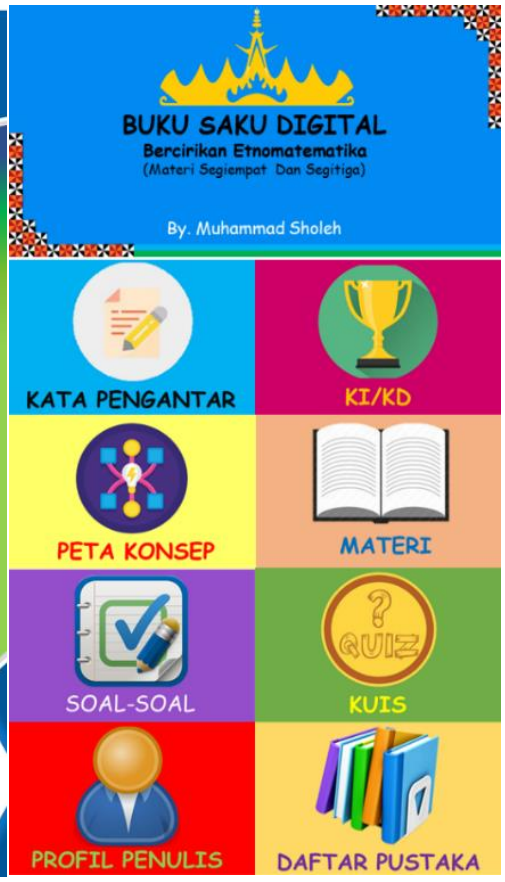

Gambar 5. Home 

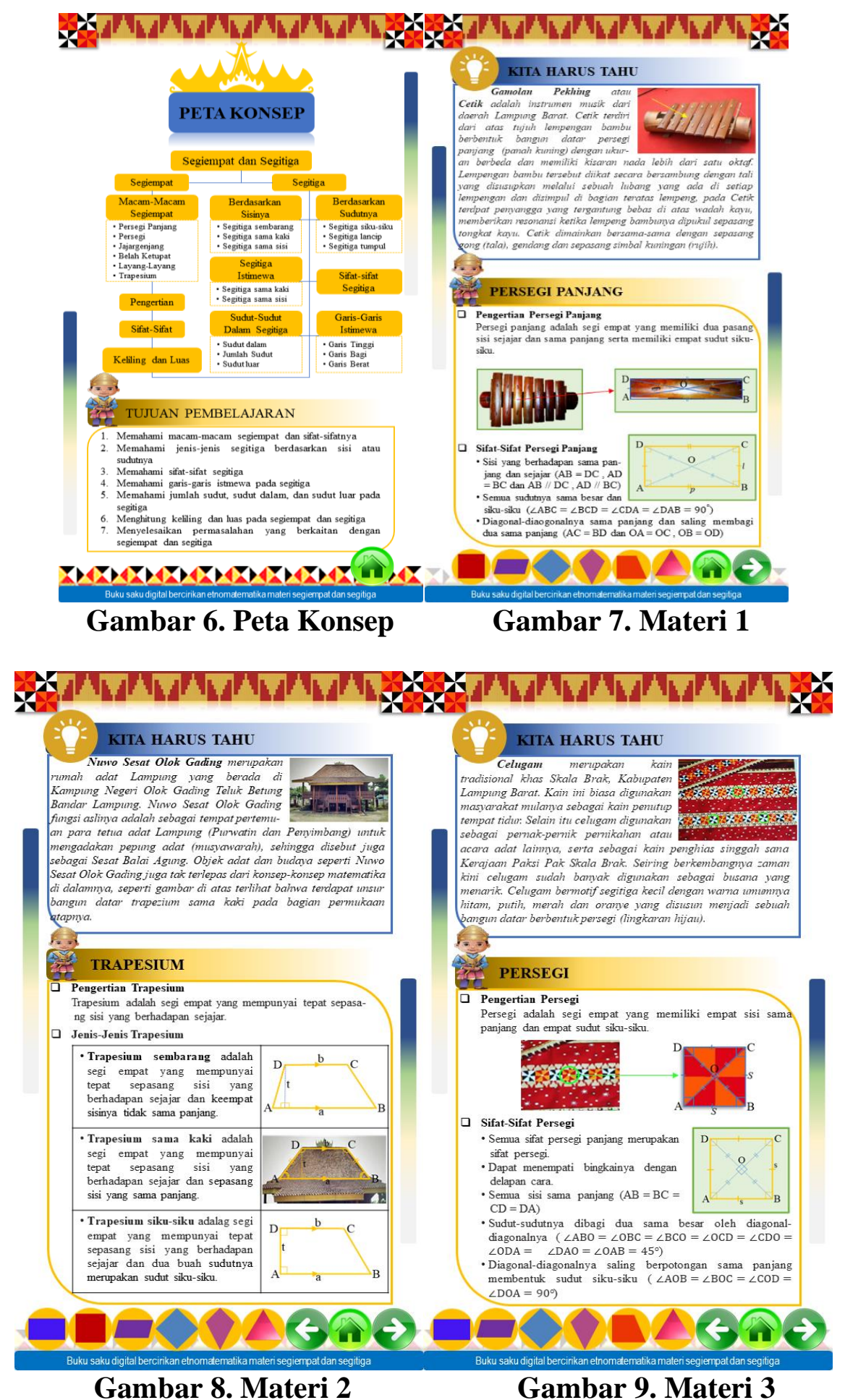

c. Uji Coba Produk

Gambar 8. Materi 2

\section{Gambar 9. Materi 3}

Uji coba dimaksudkan untuk menguji kemenarikan produk. Uji coba ini dilakukan pada peserta didik kelas VII MTs di kabupaten Lampung Barat. Uji coba dilakukan dengan cara memberikan produk kepada peserta didik untuk dilihat dan dipelajari kemudian peserta didik diberi angket untuk menilai kemenarikan produk tersebut. Tahapan uji coba produk ini dilakukan dalam dua tahap yaitu uji coba kelompok kecil dan uji coba kelompok besar. Uji coba kelompok kecil dan besar dilakukan dengan melibatkan 10 dan 25 peserta didik yang dipilih secara heterogen berdasarkan kemampuan di kelas dan jenis kelamin. Hasil uji coba produk disajikan pada Gambar 10. 


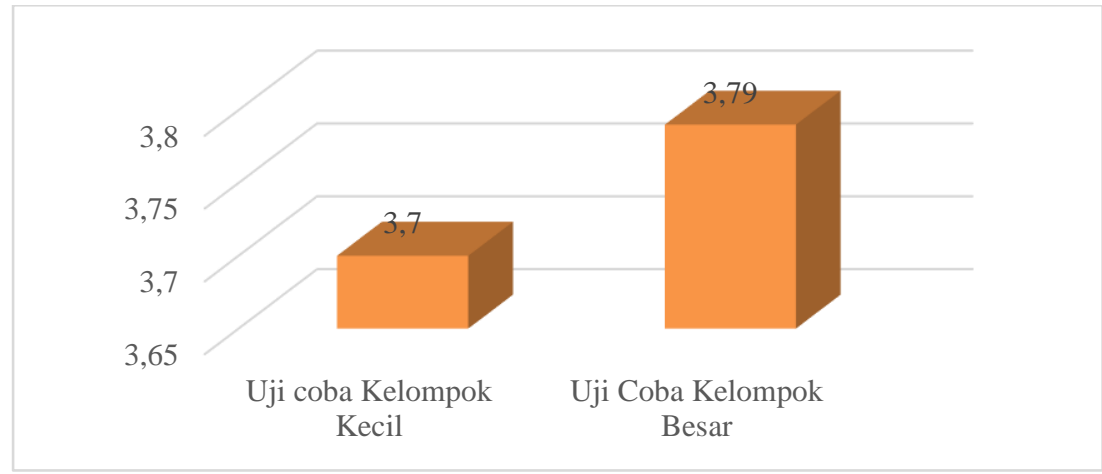

d. Uji Efektivitas Produk

Gambar 10. Hasil uji Coba Produk

Uji efektifitas produk dilakukan pada peserta didik kelas VII MTs di kabupaten Lampung Barat dengan tujuan untuk menguji keefektifan produk yang telah peneliti kembangkan. Data dalam Tabel 4. merupakan hasil uji efektifitas produk yang dikembangkan.

Tabel 4. Hasil Uji Efektifitas

\begin{tabular}{lllll}
\hline Pretest & Posttest & $\begin{array}{l}\text { Skor Maksimum } \\
\text { Ideal }\end{array}$ & $g$ & Kategori \\
\hline 40 & 83 & 100 & 0,72 & Tinggi \\
\hline
\end{tabular}

Sumber: diolah dari data penelitian

Hasil uji efektivitas produk dapat dilihat pada Tabel 4. Hasil pretest dan posttest memperoleh skor 40 dan 83, dengan skor maksimum ideal sebesar 100. Setelah dilakukan perhitungan menggunakan rumus $\mathrm{N}$-gain diperoleh skor $g$ sebesar 0,72 dengan kategori "Tinggi".

4. Tahap disseminate (penyebaran)

Produk buku saku digital berbasis android ini disebarkan ke sekolah yang telah menjadi tempat penelitian. Untuk penyebaran lebih lanjut, buku saku ini diberikan kepada pendidik atau peserta didik yang memerlukan. Selai itu, buku saku digital berbasis android bercirikan etnomatematika ini juga dapat diunduh di laman http://gg.gg/p3wsj sehingga dapat digunakan oleh siapapun secara gratis.

\section{PEMBAHASAN}

Pesatnya perkembangan teknologi digital dewasa ini telah membawa pengaruh besar bagi berbagai aspek kehidupan manusia, termasuk di bidang pendidikan (Septiyani \& Apriyanto, 2019). Maraknya pengunaan smartphone berbasis android di kalangan pelajar, seharusnya dapat dimanfaatkan sebagai media pembelajaran bagi peserta didik (Sulistri et al., 2020). Produk yang dikembangkan berupa aplikasi berbasis android, sehingga dapat dengan mudah dioperasikan karena siswa sudah terbiasa menggunakan smartphone berbasis android dalam kehidupan seharihari (Septiyani \& Apriyanto, 2019). Produk yang dikembangkan dalam penelitian ini yaitu aplikasi buku saku digital berbasis android bercirikan etnomatematika yang valid, layak, menarik dan efektif sebagai suatu media pembelajaran matematika.

Berdasarkan proses pengembangan yang telah dilakukan, buku saku digital berbasis android ini dikatakan valid dan layak digunakan apabila telah melalui beberapa proses seperti validasi, revisi, uji coba produk, dan uji efektivitas produk. Sebagian penelitian menyatakan bahwa suatu buku saku digital dinyatakan valid dan layak hanya berdasarkan hasil validasi ahli (Muhammad \& Novitasari, 2020) dan uji coba kemenarikan (Yaqin \& Rochmawati, 2017), sebagian lainnya menambakan uji efektivitas sebagai syarat suatu buku saku digital dinyatakan valid dan layak (Festiawan \& Arovah, 2020). Buku saku digital yang peneliti kembangkan melalui proses validasi, 
revisi, uji coba, hingga uji efektivitas sebagai syarat valid dan layaknya sebagai sebuah media pembelajaran. Produk yang telah selesai melakukan desain selanjutkan dilakukan validasi ahli materi dan ahli media. validasi ini dilakukan oleh pakar dan praktisi pendidikan dibidangnya masing-masing, hasil validasi ahli materi dan ahli media memperoleh skor 3,69 dan 3,75 dengan kriteria "Layak". Setelah proses validasi produk, selanjutnya dilakukan proses uji coba kelompok kecil dan kelompok besar yang dilakukan oleh peserta didik, hasil uji coba kelompok kecil dan kelompok besar memperoleh skor 3,7 dan 3,79 dengan kriteria "Sangat Menarik". Tahap terakhir yaitu uji efektivitas produk, yang dilakukan pada peserta didik dengan cara memberikan pretest dan posttest, kemudian akan dihitung menggunakan rumus $\mathrm{N}$-gain, hasil uji coba efektivitas ini diperoleh skor $N$-gain sebesar 0,72 dengan kategori "Tinggi”.

Buku saku digital pada penelitian terdahulu terbukti dapat meningkatkan kemampuan penguasaan konsep peserta didik (Awaludin \& Rostikawati, 2020), minat belajar (Afifah et. al., 2020; Fatmi \& Hadiya, 2020), pemahaman konsep (Adhyaksono et. al., 2020), hasil belajar (Hanifah et. al., 2020), dan kemampuan pemecahan masalah (Oktaviana \& Susiaty, 2020). Sementara etnomatematika dapat menanamkan nilai-nilai kebudayaan dalam diri peserta didik (Anggraeni et al., 2020), meningkatkan kemampuan pemahaman konsep peserta didik karena berkaitan erat dengan kehidupan sehari-hari (Arif et. al., 2019), lebih mudah memahami materi dan menanamkan nilai-nilai kebudayaan (Luthfiana et. al., 2020), selain itu etnomatematika dapat menciptakan lingkungan belajar dan pengalaman belajar yang mengintegrasikan budaya (Rewatus et. al., 2020). Oleh karena itu, buku saku digital berbasis android bercirikan etnomatematika menjadi sebuah media pembelajaran yang efektif digunakan dalam kegiatan belajar mengajar.

Selain bercirikan etnomatematika, buku saku digital yang peneliti kembangkan dilengkapi dengan $\mathrm{KI} / \mathrm{KD}$, peta konsep, tujuan pembelajaran, contoh soal, video pembelajaran, latihan dan penyelesaiannya, soal-soal UN dan penyelesaiannya, serta dilengkapi dengan beberapa kuis interaktif. Namun, buku saku digital ini memiliki kekurangan, yaitu materi hanya terbatas pada materi segitiga dan segiempat MTs kelas VII, serta etnomatematika yang digunakan terbatas pada kebudayaan Lampung.

\section{SIMPULAN}

Berdasarkan hasil validasi ahli, uji coba kemenarikan peserta didik, dan uji efektivitas produk, maka diperoleh simpulan bahwa buku saku digital berbasis android bercirikan etnomatematika dinyatakan valid, layak, menarik, dan efektif sebagai salah satu media pembelajaran matematika yang dapat digunakan oleh peserta didik.

\section{UCAPAN TERIMA KASIH}

Terima kasih kepada Bapak/Ibu validator atas saran dan masukannya, terimakasih kepada Bapak/Ibu kepala MTs di Kabupaten Lampung Barat yang telah memberikan izin penelitian. Terima kasih kepada semua pihak yang telah membantu peneliti dalam melakukan penelitian ini.

\section{DAFTAR RUJUKAN}

Adawiyah, R. A., Lesmono, A. D., \& Prihandono, S. H. B. (2018). Pengembangan Bahan Ajar Fisika Berupa Buku Berbasis REACT (Relating, Experiencing, Applying, Cooperating, And Transferring) Pada Pembelajaran Fisika Di SMA. JURNAL PEMBELAJARAN FISIKA, 7(2), 202-209. https://doi.org/10.19184/jpf.v7i2.7929.

Adhyaksono, R., Syafei, I., \& Putra, R. W. Y. (2020). Pengaruh Model Pembelajaran Think Talk Write (TTW) Berbantuan Buku Saku Digital terhadap Pemahaman Konsep Matematis. 
Genta Mulia: Jurnal Ilmiah Pendidikan, 11(2). https://www.ejournal.stkipbbm.ac.id/index.php/gm/article/view/456.

Afifah, N. L., Murtono, \& Santoso. (2020). Pengembangan Buku Saku Berbasis Literasi Sains untuk Meningkatkan Minat Belajar Tema Organ Gerak Hewan dan Manusia pada Siswa Sekolah Dasar. Journal for Lesson and Learning Studies, 3(3). https://doi.org/10.23887/jlls.v3i3.29774.

Anggraeni, N. A., Sunarto, A., \& Saltifa, P. (2020). Pengembangan Media Pembelajaran Prezi Berbasis Etnomatematika pada Materi Bangun Datar Kelas VII. Jurnal Equation: Teori Dan Penelitian Pendidikan Matematika, 3(2), 231-239. https://doi.org/10.29300/equation.v3i2.3631.

Arif, D. S. F., Purnomo, D., \& Sutrisno, S. (2019). Pengembangan Media Pembelajaran Interaktif Berbasis Etnomatematika Berbantu Macromedia Flash. JKPM (Jurnal Kajian Pendidikan Matematika), 4(2), 89-100. https://doi.org/10.30998/jkpm.v4i2.3673.

Asyhari, A., \& Silvia, H. (2016). Pengembangan Media Pembelajaran Berupa Buletin dalam Bentuk Buku Saku untuk Pembelajran IPA Terpadu. Jurnal Ilmiah Pendidikan Fisika AlBiruni, 5(1), 1-13. https://doi.org/10.24042/jpifalbiruni.v5i1.100.

Awaludin, M. T., \& Rostikawati, R. T. (2020). Pengembangan Buku Saku Materi Mamalia Di Taman Margasatwa Ragunan untuk Meningkatkan Penguasaan Konsep Siswa. Pedagonal: Jurnal Ilmiah Pendidikan, 4(2), 54-60. https://doi.org/10.33751/pedagonal.v4i2.2522.

Basya, Y. F., Rifa'i, A. F., \& Arfinanti, N. (2019). Pengembangan Mobile Apps Android sebagai Media Pembelajaran Matematika Berbasis Pendekatan Kontekstual untuk Memfasilitasi Pemahaman Konsep. Jurnal Pengembangan Pembelajaran Matematika, 1(1), 1-9. https://doi.org/10.14421/jppm.2019.11.1-9.

Fatmi, N., \& Hadiya, I. (2020). Development Of Environmental Physics Teaching Materials Based On Generic Science Skills In The Form Of Modules In The Form Of A Pocket Book Viewed From Student Learning Interest. Jurnal Pendidikan Fisika, 9(1), 35-41. https://doi.org/10.22611/jpf.v9i1.15129.

Ferdianto, F., \& Setiyani, S. (2018). Pengembangan Bahan Ajar Media Pembelajaran Berbasis Kearifan Lokal Mahasiswa Pendidikan Matematika. JNPM (Jurnal Nasional Pendidikan Matematika), 2(1), 37-47. https://doi.org/10.33603/jnpm.v2i1.781.

Festiawan, R., \& Arovah, N. I. (2020). Pengembangan "Buku Saku Pintar Gizi” Untuk Siswa SMP: Alternatif Media Pembelajaran untuk Meningkatkan Pengetahuan Gizi Olahraga. Physical Activity Journal (PAJU), $1(2), \quad 188-201$. https://doi.org/10.20884/1.paju.2020.1.2.2436.

Hanifah, H., Afrikani, T., \& Yani, I. (2020). Pengembangan Media Ajar E-Booklet Materi Plantae Untuk Meningkatkan Hasil Belajar Biologi Siswa. Journal Of Biology Education Research (JBER), 1(1), 10-16.

Istikomah, I., \& Purwoko, R. Y. (2020). Pengembangan E-Modul Matematika Berbasis Realisik Untuk Meningkatkan Kemampuan Berpikir Kreatif Siswa. MAJU: Jurnal Ilmiah Pendidikan Matematika, $7(2)$. https://ejournal.stkipbbm.ac.id/index.php/mtk/article/view/490.

Jabali, S. G., Supriyono, S., \& Nugraheni, P. (2020). Pengembangan Media Game Visual Novel Berbasis Etnomatematika untuk Meningkatkan Pemahaman Konsep pada Materi Aljabar. Alifmatika: Jurnal Pendidikan Dan Pembelajaran Matematika, 2(2), 185-198. https://doi.org/10.35316/alifmatika.2020.v2i2.185-198.

Khoiriyah, E., \& Sari, E. Y. (2018). Pengembangan Media Pembelajaran Pop-Up Book Pada Mata Pelajaran Ipa Kelas Iii Sdn 3 Junjung Kecamatan Suymbergempol Kabupaten Tulungagung. Jurnal Bidang Pendidikan Dasar, 2(2), 22-32. https://doi.org/10.21067/jbpd.v2i2.2495. 
Kristanti, D., \& Julia, S. (2018). Pengembangan Perangkat Pembelajaran Matematika Model 4-D Untuk Kelas Inklusi Sebagai Upaya Meningkatkan Minat Belajar Siswa. MAJU : Jurnal Ilmiah Pendidikan Matematika, $4(1)$. https://ejournal.stkipbbm.ac.id/index.php/mtk/article/view/71.

Latifah, S. (2016). Pengembangan Lembar Kerja Peserta Didik (LKPD) Berorientasi Nilai-Nilai Agama Islam melalui Pendekatan Inkuiri Terbimbing pada Materi Suhu dan Kalor. Jurnal Ilmiah Pendidikan Fisika Al-Biruni, 5(1), 43-51. https://doi.org/10.24042/jpifalbiruni.v5i1.104.

Luthfiana, M., Friansah, D., \& Marcicilia, B. (2020). Pengembangan LKS Berbasis Etnomatematika (Budaya Lubuklinggau) untuk Menumbuhkan Motivasi Belajar Matematika Siswa. Jurnal Pendidikan Matematika:Judika Education, 3(1), 1-7. https://doi.org/10.31539/judika.v3i1.1178.

Muhammad, A. F. N., \& Novitasari, N. I. (2020). Pengembangan Bahan Ajar Matematika Berbasis Etnomatematika Untuk Meningkatkan Pemahaman Matematik Siswa Kelas III Sekolah Dasar. Jurnal Bidang Pendidikan Dasar, 4(1), 80-93. https://doi.org/10.21067/jbpd.v4i1.3877.

Muhdiyanto, A. R. (2018). Pengembangan Buku Saku Digital Berbasis Android Pada Materi Matriks berdasarkan Kurikulum 2013 Di Kelas XI IPS 3 SMA Negeri 2 Sukoharjo [S1, Universitas Muhammadiyah https://doi.org/10/PERNYATAAN\%20PUBLIKASI\%20ILMIAH.pdf.

Oktaviana, D., \& Susiaty, U. D. (2020). Pengembangan Bahan Ajar Matematika Diskrit dalam Meningkatkan Kemampuan Pemecahan Masalah Matematis Mahasiswa IKIP PGRI Pontianak. SAP (Susunan Artikel Pendidikan), 4(3). https://doi.org/10.30998/sap.v4i3.6280.

Oktiana, G. D. (2015). Pengembangan Media Pembelajaran Berbasis Android dalam Bentuk Buku Saku Digital untuk Mata Pelajaran Akuntansi Kompetensi Dasar Membuat Ikhtisar Siklus Akuntansi Perusahaan Jasa Di Kelas Xi Man 1 Yogyakarta Tahun Ajaran 2014/2015. h. 118.

Putra, R. W. Y., \& Anggraini, R. (2016). Pengembangan Bahan Ajar Materi Trigonometri Berbantuan Software iMindMap pada Siswa SMA. Al-Jabar: Jurnal Pendidikan Matematika, 7(1), 39-47. https://doi.org/10.24042/ajpm.v7i1.129.

Ramadhani, R. (2016). Pengembangan Perangkat Pembelajaran Matematika yang Berorientasi pada Model Problem Based Learning. Kreano, Jurnal Matematika Kreatif-Inovatif, 7(2), 116-122. https://doi.org/10.15294/kreano.v7i2.7300.

Rewatus, A., Leton, S. I., Fernandez, A. J., \& Suciati, M. (2020). Pengembangan Lembar Kerja Peserta Didik Berbasis Etnomatematika Pada Materi Segitiga dan Segiempat. Jurnal Cendekia: Jurnal Pendidikan Matematika, 4(2), 645-656. https://doi.org/10.31004/cendekia.v4i2.276.

Rohmaini, L., Netriwati, N., Komarudin, K., Nendra, F., \& Qiftiyah, M. (2020). Pengembangan Modul Pembelajaran Matematika Berbasis Etnomatematika Berbantuan Wingeom Berdasarkan Langkah Borg And Gall. Teorema: Teori dan Riset Matematika, 5(2), 176186. https://doi.org/10.25157/teorema.v5i2.3649.

Salbino, S. (2014). Buku Pintar Gadget Android Untuk Pemula (1st ed.). Kunci Komunikasi.

Septiyani, E., \& Apriyanto, M. T. (2019). Pengembangan Media Pembelajaran Matematika Berbasis Android untuk Tingkat SMP. JKPM (Jurnal Kajian Pendidikan Matematika), 5(1), 153-164. https://doi.org/10.30998/jkpm.v5i1.5230.

Sugiyono, S. (2015). Metode Penelitian Pendidikan pendekatan Kuantitatif, Kualitatif, dan R\&D. Alfabeta.

Suherman, S. (2018). Ethnomathematics: Eksploration of Traditional Crafts Tapis Lampung as Ilustration of Science, Technology, Engineering, and Mathematics (STEM). Eduma: 
Mathematics Education Learning and Teaching, 7(2). https://doi.org/10.24235/eduma.v7i2.3085.

Sulistri, E., Sunarsih, E., \& Utama, E. G. (2020). Pengembangan Buku Saku Digital Berbasis Etnosains di Sekolah Dasar Kota Singkawang. Jurnal Kependidikan: Jurnal Hasil Penelitian dan Kajian Kepustakaan di Bidang Pendidikan, Pengajaran dan Pembelajaran, 6(3), 522-531. https://doi.org/10.33394/jk.v6i3.2842

Supriadi, N. (2015). Mengembangkan Kemampuan Koneksi Matematis Melalui Buku Ajar Elektronik Interaktif (BAEI) yang Terintegrasi Nilai-nilai Keislaman. Al-Jabar : Jurnal Pendidikan Matematika, 6(1), 63-74. https://doi.org/10.24042/ajpm.v6i1.51.

Syahroni, M., Nurrochmah, S., \& Amiq, F. (2016). Pengembangan Buku Saku Elektronik Berbasis Android tentang Signal-Signal Wasit Fitsal untuk Wasit Futsal Di Kabupaten Pasuruan. Jurnal Pendidikan Jasmani, 26(2). https://doi.org/10.17977/pj.v26i2.7508.

Wahyuni, S., Yati, M., \& Fadila, A. (2020). Pengembangan Modul Matematika Berbasis REACT terhadap Kemampuan Komunikasi Matematis Peserta Didik. Jambura Journal of Mathematics Education, 1(1), 1-12. https://doi.org/10.34312/jmathedu.v1i1.4542.

Yaqin, A., \& Rochmawati. (2017). Pengembangan Buku Saku Digital Berbasis Android sebagai Pendukung Bahan Ajar pada Materi PPh Pasal 21. Jurnal Pendidikan Akuntansi (JPAK), 5(1). https://jurnalmahasiswa.unesa.ac.id/index.php/jpak/article/view/17965. 